\title{
Dampak Mediasi Struktur Modal terhadap hubungan Profitabilitas, Kebijakan Dividen, dan Ukuran Perusahaan serta Nilai Perusahaan
}

(Studi pada Perusahaan Manufaktur yang Listing di Bursa Efek Indonesia Periode 2012-2016)

\author{
Zulfa Latifia Hanif \\ Yulianti \\ Farikha Amilahaq \\ Universitas Semarang \\ Universitas Islam Sultan Agung \\ zulfa.latifia@gmail.com \\ farikha@unissula.ac.id
}

\begin{abstract}
This research focuses on efforts to increase company value by the level of profitability, dividend policy, and company size. The novelty of the model is to use capital structure as intervening. The population focuses on manufacturing companies that have gone public on the Indonesia Stock Exchange at least from 2012 to 2016, namely as many as 139 companies. While the sampling technique is purposive sampling and obtained by 33 companies.Based on the results of the analysis using path analysis techniques, it can be concluded that the structure model (DER) is not able to mediate the role of profitability (ROE) on firm value (PBV). The dividend policy (DPR) and company size do not have direct implications on the value of the company, but rather through dividend policy as an intermediary. This study found that there is an effect of profitability, dividend policy, and company size on firm value through capital structure as an intervening variable.
\end{abstract}

Keywords : Profitability, Dividend Policy, Firm Size, Firm Value, Capital Structure.

\section{ABSTRAK}

Penelitian ini berfokus pada upaya peningkatan nilai perusahaan oleh tingkat profitabilitas, kebijakan dividen, serta ukuran perusahaan. Kebaharuan model ialah menggunakan struktur modal sebagai intervening. Adapun populasi berfokus pada perusahaan manufaktur yang telah go publik di Bursa Efek Indonesia setidaknya dari tahun 2012 hingga 2016, yakni sebanyak 139 perusahaan. Sementara teknik pengambilan sampel ialah purposive sampling dan diperoleh 33 perusahaan. Berdasarkan hasil analisis menggunakan teknik analisis jalur, dapat disimpulkan bahwa struktur model (DER) tidak mampu memediasi peran profitabilitas (ROE) terhadap nilai perusahaan (PBV). Adapun kebijakan dividen (DPR) dan ukuran perusahaan tidak berimplikasi secara langsung pada nilai perusahaan, melainkan melalui kebijakan dividen sebagai perantara. Penelitian ini menemukan bahwa ada pengaruh profitabilitas, kebijakan dividen, dan ukuran perusahaan terhadap nilai perusahaan melalui struktur modal sebagai variabel intervening.

Kata kunci : $\quad$ Profitabilitas, Kebijakan Dividen, Ukuran Perusahaan, Nilai Perusahaan, Struktur Modal. 


\section{PENDAHULUAN}

Perusahaan go public tidak hanya berorientasi untuk tercapainya laba maksimal, tetapi juga berusaha mensejahterakan pemegang saham dan lebih meningkatkan nilai perusahaan, sehingga perusahaan harus memiliki strategi yang tepat (Khoirianto, 2016). Memaksimalkan nilai perusahaan sama halnya memaksimalkan nilai sekarang dari semua keuntungan yang akan diterima oleh pemegang saham di masa yang akan datang.

Dalam penelitian ini akan membahas mengenai beberapa faktor-faktor yang dapat menyebabkan penurunan dan peningkatan nilai perusahaan diantaranya ialah profitabilitas, kebijakan dividen, dan struktur modal dengan mengembangkan variabel lain yaitu ukuran perusahaan (Khoirianto, 2016). Beberapa faktor tersebut (profitabilitas, dividen, dan struktur modal) memiliki hubungan dan pengaruh terhadap nilai perusahaan yang tidak konsisten. Karena ketidak konsistenan hasil penelitian, dalam penelitian ini profitabilitas, dividen, dan struktur modal digunakan sebagai faktor-faktor yang mempengaruhi perusahaan (Khoirianto, 2016).

Dalam meningkatkan nilai perusahaan, hal yang tidak bisa dipisahkan adalah bagaimana penentuan struktur modal yang akan dilakukan manajemen dan para pemegang saham perusahaan. Dengan mengelola struktur modal yang tepat, akan membantu tercapainya tujuan perusahaan, maka pentingnya perusahaan untuk memperhatikan struktur modal perusahaan. Pentingnya struktur modal bagi suatu perusahaan karena struktur modal memiliki suatu efek langsung terhadap posisi keuangan perusahaan sehingga perusahaan harus mengetahui faktor-faktor yang mempengaruhi struktur modal agar dapat memaksimalkan kemakmuran pemegang saham dalam perusahaan. Keputusan pendanaan (struktur modal) secara langsung juga mempengaruhi besarnya risiko yang harus ditanggung oleh pemilik modal, serta besarnya tingkat return (Brigham \& Houston, 2011).

Keputusan struktur modal adalah keputusan yang sangat penting bagi hidup perusahaan dan untuk menentukan suatu risiko keuangan meliputi beberapa kemungkinan perusahaan dengan kewajiban membayar dan laba yang ditargetkan kemungkinan tidak tercapai (Brigham \& Houston, 2011, p. 155). Struktur modal diharapkan dapat memenuhi harapan investor dan tidak menghambat pertumbuhan perusahaan, karena semakin besar dividen yang telah dibayarkan maka semakin sedikit jumlah laba yang ditahan, akibatnya akan menghambat pertumbuhan perusahaan dan akan menurunkan harga sahamnya. Pertumbuhan perusahaan secara terus menerus diharapkan dapat mempertahankan kelangsungan hidup dan kemakmuran yang lebih tinggi kepada pemilik saham.

Beberapa penelitian yang berkaitan dengan profitabilitas, kebijakan dividen, ukuran perusahaan dan struktur modal terhadap nilai perusahaan dapat disimpulkan bahwa terdapat research gap dengan hasil penelitian terdahulu. Data research gap tersebut disusun dalam bentuk tabel seperti berikut.

Berdasarkan hasil Research Gap tersebut, ada faktor (profitabilitas, kebijakan dividen, ukuran perusahaan dan struktur modal) memiliki hubungan dan pengaruh terhadap nilai perusahaan. Penelitian ini merupakan pengembangan dari peneliti (Khoirianto, 2016) dengan penambahan variabel penelitian dan periode penelitian. Tujuan utama dari studi ini adalah untuk menguji pengaruh profitabilitas, kebijakan dividen, ukuran perusahaan, dan struktur modal terhadap nilai perusahaan di Bursa Efek Indonesia periode 2012-2016. Objek 
Tabel 1. Data Research Gap

\begin{tabular}{|c|c|c|c|c|}
\hline \multirow{2}{*}{ Independen } & \multicolumn{2}{|c|}{ Struktur Modal } & \multicolumn{2}{|l|}{ Nilai Perusahaan } \\
\hline & Sign & Tidak Sign & Sign & Tidak Sign \\
\hline Profitabilitas & $\begin{array}{l}\text { (Hermuningsih, } \\
\text { 2013; Khoirianto, } \\
\text { 2016; Pradana, 2015; } \\
\text { Wulandari, 2013) }\end{array}$ & $\begin{array}{l}\text { (Junita, 2014; } \\
\text { Nainggolan, 2017; } \\
\text { Rubiyani \& Yuniati, } \\
\text { 2016) }\end{array}$ & $\begin{array}{l}\text { (Hermuningsih, 2013; Khoirianto, } \\
\text { 2016; Rubiyani \& Yuniati, 2016; } \\
\text { Suffah \& Riduwan, 2016) }\end{array}$ & (Asmidar, 2015) \\
\hline Kebijakan Dividen & (Khoirianto, 2016) & $\begin{array}{l}\text { (Nainggolan, 2017; } \\
\text { Pradana, 2015) }\end{array}$ & $\begin{array}{c}\text { (Asmidar, 2015; Suffah \& } \\
\text { Riduwan, 2016) }\end{array}$ & (Khoirianto, 2016) \\
\hline $\begin{array}{c}\text { Ukuran } \\
\text { Perusahaan }\end{array}$ & (Hermuningsih, 2013) & $\begin{array}{c}\text { (Junita, 2014; } \\
\text { Nainggolan, 2017) }\end{array}$ & $\begin{array}{c}\text { (Asmidar, 2015; Hermuningsih, } \\
\text { 2013) }\end{array}$ & $\begin{array}{c}\text { (Suffah \& } \\
\text { Riduwan, 2016) }\end{array}$ \\
\hline Struktur Modal & & & $\begin{array}{c}\text { (Hermuningsih, 2013; Khoirianto, } \\
\text { 2016; Rubiyani \& Yuniati, 2016; } \\
\text { Wulandari, 2013) }\end{array}$ & \\
\hline
\end{tabular}

Sumber : berbagai jurnal

penelitian yang digunakan adalah perusahaan manufaktur yang listing di Bursa Efek Indonesia tahun 20122016.

\section{KAJIAN PUSTAKA}

\section{Struktur Modal}

Struktur modal adalah perimbangan atau perbandingan antara jumlah hutang jangka panjang dengan modal sendiri (Hermuningsih, 2013). Struktur modal berkaitan dengan pemilihan sumber dana baik yang dari dalam maupun luar perusahaan. Pentingnya struktur modal bagi suatu perusahaan karena struktur modal memiliki suatu efek langsung terhadap posisi keuangan perusahaan. Karena itu perusahaan harus mengetahui faktor-faktor yang mempengaruhi struktur modal agar dapat memaksimalkan kemakmuran pemegang saham dalam perusahaan. Perusahaan dapat melakukan perubahan struktur modal untuk mencapai struktur modal yang optimal dalam perusahaan. Struktur modal yang baik ialah yang mencapai keseimbangan antara risiko dan return, sehingga dapat memaksimalkan nilai perusahaan (Brigham \& Houston, 2011, p. 155).

\section{Nilai Perusahaan}

Nilai perusahaan merupakan nilai yang dapat digunakan untuk mengukur seberapa besar "Tingkat Kepentingan" sebuah perusahaan dilihat dari sudut pandang beberapa pihak seperti para investor yang mengaitkan nilai sebuah perusahaan dari harga sahamnya. Nilai perusahaan yang tinggi merupakan jaminan bagi para investor dalam menanamkan modalnya (Khoirianto, 2016). Karena tingginya nilai perusahaan ini dapat mencerminkan kemakmuran pemegang saham. Maka nilai perusahaan dapat diartikan sebagai tingkat ekspektasi nilai investasi pemegang saham (harga pasar ekuitas) ataupun ekspektasi nilai total perusahaan (harga pasar ekuitas dijumlahkan dengan nilai pasar utang), ataupun ekspektasi nilai pasar aktiva (Farikhah, 2015).

Nilai potensial suatu perusahaan dapat dilihat atas dua hal, yaitu modal keuangan dan modal intelektual. 
CEO-CEO perusahaan seringnya terlalu fokus pada aspek keuangan, padahal modal intelektual merupakan faktor penting dalam paradigman organisasi di era global ini (Nofrita, 2013).

\section{Profitabilitas}

Profitabilitas merupakan kemampuan perusahaan untuk menghasilkan laba pada tingkat penjualan tertentu dalam periode tertentu (Copeland \& Weston, 1992). Profitabilitas juga dapat mencerminkan kemampuan manajemen untuk memperoleh laba (Utari, 2014, p. 63). Sedangkan pendapat lain menurut profitabilitas adalah tingkat keuntungan yang diperoleh oleh perusahaan pada saat menjalankan operasinya. Profitabilitas adalah rasio dari efektifitas manajemen berdasarkan hasil pengembalian yang dihasilkan dari penjualan dan investasi.

\section{Kebijakan Dividen}

Dividen ialah besarnya laba yang didistribusikan kepada pemegang saham pada periode usaha (Walsh, 2004, p. 152). Kebijakan dividen dalam definisi lain merupakan keputusan apakah laba yang diperoleh perusahaan akan dibagi kepada pemegang saham dalam bentuk dividen ataukah akan ditahan untuk menambah modal guna membiayai bisnisnya (investasi) di masa mendatang (Suffah \& Riduwan, 2016). Kebijakan dividen sering dianggap sebagai signal bagi investor dalam menilai baik buruknya perusahaan, hal ini disebabkan karena kebijakan dividen dapat membawa pengaruh terhadap harga saham perusahaan (Mardiyati, 2012).

\section{Ukuran Perusahaan}

Ukuran perusahaan menunjukkan besar kecilnya kapitalisasi bisnis suatu perusahaan, yakni ditunjukkan pada total aktiva, jumlah penjualan, rata-rata total aktiva (Riyanto, 2008). Salah satu tolak ukur yang menunjukkan besar kecilnya perusahaan adalah ukuran dari perusahaan tersebut, maka semakin besarnya total asset perusahaan semakin besar ukuran perusahaan. Jika perusahaan memiliki total asset yang besar, pihak manajemen lebih leluasa dalam mempergunakan asset yang ada di perusahaan tersebut khususnya untuk operasi perusahaan. Keleluasaan pihak manajemen tersebut berbanding lurus dengan meningkatnya tingkat kekhawatiran oleh pemilik modal (Farikhah, 2015).

\section{Hubungan antar Variabel}

Hubungan Profitabilitas terhadap Struktur Modal

Perusahaan yang memiliki laba tinggi umumnya lebih banyak menggunakan fasilitas kredit perbankan karena laba kena pajak yang terlindungi. Hasil penelitian dari (Khoirianto, 2016) menyimpulkan profitabilitas berpengaruh positif dan signifikan terhadap struktur modal. Dengan demikian dapat disusun hipotesis sebagai berikut.

$\mathrm{H}_{1}$ : Profitabilitas berpengaruh positif terhadap Struktur Modal

\section{Pengaruh Hubungan Kebijakan Dividen terhadap Struktur Modal}


Pembayaran dividen muncul sebagai pengganti hutang di dalam struktur modal untuk mengawasi perilaku manajer. Keterkaitan kebijakan dividen dengan struktur modal ialah ketika perusahaan memutuskan untuk meningkatkan dividen maka laba yang ditahan akan semakin kecil, sehingga sumber pendanaan perusahaan akan lebih mengandalkan sumber pendanaan eksternal seperti hutang (Khoirianto, 2016). Dengan demikian dapat disusun hipotesis sebagai berikut.

$\mathrm{H}_{2}$ : Kebijakan Dividen berpengaruh terhadap Struktur Modal

\section{Pengaruh Hubungan Ukuran Perusahaan terhadap Struktur Modal}

Ukuran perusahaan yang sudah besar cenderung membuat kebijakan pendanaan bukan berasal dari utang (struktur modal). Karena ukuran perusahaan yang besar menunjukkan kemampuan pendanaan internal perusahaan. Dalam penelitian dari Dewi dan Sudiartha (2017) yang menyatakan bahwa terdapat pengaruh antara ukuran perusahaan terhadap struktur modal. Hal ini dikarenakan semakin besar ukuran perusahaan cenderung membuat manajemen mengambil kebijakan untuk menggunakan lebih sedikit sumber dana eksternal seperti utang sebagai sumber pendanaan bisnis mereka. Dengan demikian dapat disusun hipotesis sebagai berikut.

$\mathrm{H}_{3}$ : Ukuran Perusahaan berpengaruh terhadap Struktur Modal

\section{Hubungan Profitabilitas terhadap Nilai Perusahaan}

Penelitian (Meidiawati \& Mildawati, 2016), ROE berpengaruh terhadap nilai perusahaan. Hasil penelitian ini sejalan dengan (Suffah \& Riduwan, 2016) hasil penelitian profitabilitas berpengaruh positif dan signifikan pada nilai perusahaan. Nilai profitabilitas yang tinggi menunjukkan kinerja perusahaan meningkat dan diperkirakan mempunyai prospek masa depan yang baik. Perusahaan mempunyai prospek yang bagus di masa mendatang akan memicu investor untuk ikut meningkatkan permintaan saham. Permintaan saham yang meningkat akan menyebabkan nilai perusahaan juga ikut meningkat. Dengan demikian dapat disusun hipotesis sebagai berikut.

$\mathrm{H}_{4}$ : Profitabilitas berpengaruh terhadap Nilai Perusahaan

\section{Pengaruh Hubungan Kebijakan Dividen terhadap Nilai Perusahaan}

Pembayaran dividen mencerminkan kondisi keuangan perusahaan dan memiliki dampak terhadap persepsi pasar (Riyanto, 2008). Jika pembayaran dividen tinggi, maka harga saham juga akan tinggi, sehingga akan berdampak pula pada tingginya nilai perusahaan (Meidiawati \& Mildawati, 2016). Dengan membayarkan dividen kepada pemegang saham maka akan menaikkan nilai perusahaan (Farikhah, 2015). Investor akan cenderung untuk berinvestasi pada perusahaan yang dapat memberikan kepastian pembagian keuntungan berupa dividen secara teratur. Dengan kata lain, kebijakan dividen berpengaruh positif dan signifikan terhadap nilai perusahaan (Asmidar, 2015; Suffah \& Riduwan, 2016). Dengan demikian dapat disusun hipotesis sebagai berikut.

$\mathrm{H}_{5}$ : Kebijakan Dividen berpengaruh terhadap Nilai Perusahaan 


\section{Pengaruh Hubungan Ukuran Perusahaan terhadap Nilai Perusahaan}

Perusahaan besar umumnya memiliki kendali yang baik atas kondisi di pasar. Perusahaan lebih mampu menghadapi persaingan bisnis serta fluktuasi kondisi ekonomi (Meidiawati \& Mildawati, 2016). Berdasarkan pengujian dari (Asmidar, 2015; Putri, 2014) menyatakan bahwa ukuran perusahaan memiliki pengaruh yang signifikan terhadap nilai perusahaan. Ukuran perusahaan yang meningkat dapat meningkatkan kepercayaan investor serta calon investor untuk menanamkan modalnya pada perusahaan. Karena itu perusahaan akan terus didorong untuk dapat meningkatkan kapitalisasi asetnya, serta menjaga pengelolaan perusahaan yang baik, sehingga dapat meningkatkan nilai perusahaan. Dengan demikian dapat disusun hipotesis sebagai berikut.

$\mathrm{H}_{6}$ : Ukuran Perusahaan berpengaruh terhadap Nilai Perusahaan

\section{Hubungan Struktur Modal terhadap Nilai Perusahaan}

Hutang yang semakin tinggi berdampak pada menurunnya probabilitas kemampuan perusahaan untuk memenuhi tanggungjawabnya tersebut, yakni membayar bunga serta mengembalikan pokok hutang. Karena itu risiko kebangkrutan semakin meningkat, terlebih karena beban bunga lebih tinggi daripada toleransi pajaknya (Susanto, 2016).

Hasil dari penelitian (Hermuningsih, 2013; Rubiyani \& Yuniati, 2016) menunjukkan bahwa terdapat pengaruh positif dan signifikan dari struktur modal terhadap nilai perusahaan. Hal ini dikarenakan semakin tinggi struktur modal maka nilai perusahaan yang tercermin pada harga saham perusahaan semakin tinggi. Hasil ini juga sejalan dengan teori struktur modal yang menjelaskan bahwa ada pengaruh struktur modal terhadap nilai perusahaan. Dengan demikian dapat disusun hipotesis sebagai berikut.

$\mathrm{H}_{7}$ : Struktur Modal berpengaruh terhadap Nilai Perusahaan

\section{Hubungan Profitabilitas Terhadap Nilai Perusahan Melalui Struktur Modal}

Perusahaan yang berhasil membukukan laba yang meningkat, mengindikasikan perusahaan tersebut mempunyai kinerja yang baik. Ketika keputusan pendanaan sudah tepat, maka dapat menciptakan sentiment positif para investor dan dapat membuat harga saham perusahaan meningkat. Meningkatnya harga saham di pasar, maka akan meningkatkan nilai perusahaan. Hasil penelitian (Khoirianto, 2016) menemukan bukti bahwa profitabilitas berpengaruh terhadap struktur modal, dan struktur modal berpengaruh terhadap nilai perusahaan. Dengan demikian dapat disusun hipotesis sebagai berikut.

$\mathrm{H}_{8}$ : Profitabilitas berpengaruh terhadap Nilai Perusahaan melalui Struktur Modal

\section{Pengaruh Hubungan Kebijakan Dividen Terhadap Nilai Perusahan Melalui Struktur Modal}

Pembayaran dividen dapat meningkatkan penggunaan hutang sebagai sumber pendanaan eksternal dalam operasi perusahaan. Dengan adanya penggunaan hutang akan terjadi penghematan pajak yang pada akhirnya meningkatkan nilai perusahaan. Penelitian dari (Khoirianto, 2016) menemukan bukti bahwa kebijakan dividen berpengaruh terhadap struktur modal dan struktur modal berpengaruh terhadap nilai perusahaan. Dengan demikian dapat disusun hipotesis sebagai berikut. 


\section{$\mathrm{H}_{9}$ : Kebijakan Dividen berpengaruh terhadap Nilai Perusahaan melalui Struktur Modal}

\section{Pengaruh Hubungan Ukuran Perusahaan Terhadap Nilai Perusahan Melalui Struktur Modal}

Perusahaan yang berada pada pertumbuhan penjualan yang tinggi membuat dukungan sumber daya organisasi (modal) yang semakin besar, demikian juga sebaliknya, pada perusahaan yang tingkat pertumbuhan penjualannya rendah kebutuhan terhadap sumber daya organisasi (modal) juga semakin kecil. Menurut (Hermuningsih, 2013) ukuran perusahaan berpengaruh terhadap nilai perusahaan melalui struktur modal. Dengan demikian dapat disusun hipotesis sebagai berikut:

$\mathrm{H}_{10} \quad$ : Ukuran Perusahaan berpengaruh terhadap Nilai Perusahaan melalui Struktur Modal

\section{METODOLOGI}

Penelitian menjadikan profitabilitas, kebijakan dividen, dan ukuran perusahaan sebagai variabel bebas, nilai perusahaan sebagai variabel terikat, dan struktur modal sebagai variabel antara. Adapun objek penelitian berfokus pada perusahaan manufaktur yang telah go publik di IDX selama periode penelitian 2012-2016. Maka dapat dikatakan bahwa penelitian ini bersifat kuantitatif dengan sumber data dari ringkasan laporan tahunan perusahaan-perusahaan sampel.

\section{Metode Analisis Data}

Penelitian ini bertujuan menguji hipotesis, maka metode yang digunakan adalah analisis linear berganda dan model analisis jalur (path analysis). Adapun tahapan dalam menganalisis data adalah menganalisa hasil statistik deskriptif (Ghozali, 2014), melakukan uji asumsi klasik pada data diantaranya ialah uji normalitas, uji

Tabel 2. Definisi Operasional Variabel

\begin{tabular}{|c|c|c|c|}
\hline Nama Variabel & Definisi dan Indikator & Satuan & Sumber \\
\hline Nilai Perusahaan & $\begin{array}{l}\text { PBV }= \\
\text { Mengukur seberapa besar "Tingkat Kepentingan" sebuah } \\
\text { perusahaan dilihat dari sudut pandang beberapa pihak seperti } \\
\text { para investor yang mengaitkan nilai sebuah perusahaan dari } \\
\text { harga sahamnya }\end{array}$ & Rasio & $\begin{array}{l}\text { (Brigham } 8 \\
\text { Houston, 2011) }\end{array}$ \\
\hline Profitabilitas & $\begin{array}{l}\mathrm{ROE}= \\
\text { Kemampuan manajemen untuk memperoleh laba. }\end{array}$ & Rasio & $\begin{array}{l}\text { (Brigham } 8 \\
\text { Houston, 2011) }\end{array}$ \\
\hline Kebijakan Dividen & $\begin{array}{l}\text { DPR = } \\
\text { Besarnya laba yang dibagikan kepada pemegang saham pada } \\
\text { akhir tahun yang juga akan mencerminkan besarnya laba yang } \\
\text { akan ditanamkan pada laba ditahan pada akhir tahun. }\end{array}$ & Rasio & (Walsh, 2004) \\
\hline $\begin{array}{l}\text { Ukuran } \\
\text { Perusahaan }\end{array}$ & $\begin{array}{l}\text { SIZE }= \\
\text { Ukuran perusahaan diukur dari logaritma natural dari total asset } \\
\text { yang dimiliki oleh perusahaan }\end{array}$ & Ratio & (Farikhah, 2015) \\
\hline Struktur Modal & $\begin{array}{l}\text { DER }= \\
\text { Perimbangan jumlah utang jangka pendek yang bersifat } \\
\text { permanen, utang jangka panjang, saham prefer dan saham biasa. }\end{array}$ & Rasio & (Walsh, 2004) \\
\hline
\end{tabular}

Sumber: (Brigham \& Houston, 2011; Farikhah, 2015; Walsh, 2004) 
multikolinearitas, uji heteroskedastisitas, serta uji autokorelasi. Tahapan analisis ketiga ialah menguji hipotesis menggunakan uji t. Model berupa analisis jalur sehingga pengujian hipotesis dilakukan dengan dua kali analisis regresi, yakni nilai perusahaan sebagai variabel akhir, dan struktur modal sebagai variabel akhir. Pengujian hubungan tidak langsung tersebut juga perlu dilakukan, yakni dengan uji sobel. Alat bantu pengolahan data menggunakan program SPSS 20.

\section{HASIL DAN PEMBAHASAN}

Data dalam penelitian ini diperoleh 139 perusahaan manufaktur yang menjadi populasi. Dari populasi tersebut selanjutnya dipilih sampel berdasarkan metode purposive sampling dengan tujuan untuk mendapatkan sampel yang representative sesuai dengan kriteria yang ditentukan. Beberapa kriteria yang ditetapkan untuk memperoleh sampel dalam penelitian ini sebagai berikut.

Tabel 3. Proses Pengambilan Sampel

\begin{tabular}{lc}
\hline \multicolumn{1}{c}{ Kriteria } & Jumlah \\
\hline Perusahaan manufaktur yang listing di IDX periode 2012-2016 & 139 \\
\hline $\begin{array}{l}\text { Perusahaan tidak menerbitkan laporan keuangan yang telah diaudit dan } \\
\text { mempublikasikan laporan keuangan secara terus-menerus selama periode }\end{array}$ & $(11)$ \\
penelitian & $(30)$ \\
\hline $\begin{array}{l}\text { Perusahaan tidak menyajikan laporan keuangan dengan mata uang rupiah } \\
\text { selama periode penelitian }\end{array}$ & $(37)$ \\
\hline $\begin{array}{l}\text { Perusahaan tidak memiliki laba positif (tidak mengalami kerugian) selama } \\
\text { periode penelitian }\end{array}$ & 33 \\
\hline Perusahaan tidak yang membagikan dividen selama periode penelitian & 5 \\
\hline Jumlah sampel yang digunakan & 165 \\
\hline Jahun penelitian tahun 2012-2016
\end{tabular}

Sumber : BEl, data diolah

Berdasarkan kriteria sampel tersebut, maka dalam penelitian ini sampel yang memenuhi syarat adalah sebanyak 33 perusahaan dengan periode waktu penelitian 2012-2016 maka jumlah data dalam penelitian ini sebanyak 165 data, 33 perusahaan yang memenuhi kriteria untuk dijadikan sampel dalam penelitian ini sebagai berikut.

\section{Analisis Deskriptif}

Analisis deskriptif yang berdasarkan atas data sampel yang bersumber dari laporan keuangan perusahaan go public yang dipublikasikan dalam IDX 2012-2016 telah diperoleh deskripsi mengenai variabel-variabel yang digunakan dalam penelitian. Berikut disajikan hasil dari statistik deskriptif.

Rata-rata (mean) nilai perusahaan (PBV) sebesar 5,6473 dengan standar deviasi sebesar 10,1367, 
Tabel 4. Statistik Deskriptif

Descriptive Statistics

\begin{tabular}{|l|r|r|r|r|r|}
\hline & \multicolumn{1}{|c|}{ N } & Minimum & Maximum & \multicolumn{1}{c|}{ Mean } & Std. Deviation \\
\hline PBV & 165 & .1402 & 62.9311 & 5.647381 & 10.1367832 \\
DER & 165 & .1502 & 3.0286 & .689225 & .5048846 \\
ROE & 165 & .0129 & 1.4353 & .249544 & .2750515 \\
SIZE & 165 & 25.5796 & 33.1988 & 28.967611 & 1.7696685 \\
DPR & 165 & .0233 & 1.7183 & .434249 & .3166438 \\
Valid N (listwise) & 165 & & & & \\
\hline
\end{tabular}

Sumber: Data sekunder yang diolah SPSS 20, 2019

kondisi ini menunjukkan bahwa perusahaan-perusahaan manufaktur yang terdaftar di BEI mempunyai nilai perusahaan relatif berbeda jauh antara satu dengan yang lain. Nilai minimum PBV adalah sebesar 0,1402, dan nilai maximum PBV adalah sebesar 62,9311. Adapun berdasarkan data struktur modal (DER), menunjukkan bahwa perusahaan manufaktur di BEI memiliki kebijakan struktur modal yang hampir sama (nilai rata-rata dan standar deviasi yang tidak terlalu tinggi). Begitu pula dengan tingkat pengembaliannya (profitabilitas/ROE) serta return yang diberikan kepada investor (kebijakan dividen). Meski demikian ukuran perusahaan relatif berbeda jauh antara satu dengan yang lain..

\section{Uji Asumsi Klasik}

Dalam upaya memastikan suatu data dan model terbebas dari asumsi klasik, maka perlu dilakukan beberapa uji, yaitu uji normalitas, uji multikolinearitas, uji heteroskedastisitas, dan uji autokorelasi. Uji asumsi klasik tersebut dilakukan untuk setiap model regresi, yakni model regresi pertama dan kedua. Hasil uji asumsi klasik pada kedua model menunjukkan bahwa data telah bersifat normal, terbebas dari asumsi multikolinearitas, data bersifat homoskedastisitas (bebas dari asumsi heteroskedastisitas), serta tidak terdapat indikasi autokorelasi. Maka dari itu, dapat dilakukan uji selanjutnya yaitu uji asumsi klasik, serta mengestimasi model regresi yang terbaik.

\section{Uji Hipotesis}

Pengujian penelitian menggunakan SPSS versi 20 untuk menguji keseluruhan hipotesis dengan menggunakan analisis jalur (path analysis). Analisis ini merupakan perluasan dari analisis regresi linear berganda. Path analysis bertujuan untuk mengetahui adanya pengaruh langsung ROE (profitabilitas), DPR (kebijakan dividen), dan SIZE (ukuran perusahaan) terhadap PBV (nilai perusahaan) dan pengaruh tidak langsung ROE (profitabilitas), DPR (kebijakan dividen), dan SIZE (ukuran perusahaan) terhadap PBV (nilai perusahaan) dengan DER (struktur modal) sebagai variabel intervening. Secara statistik dapat diukur dari nilai statistik F, statistik t dan koefisien determinasi $\left(R^{2}\right)$. 


\section{Uji Simultan (Uji F)}

Hasil uji statistik F menunjukkan apakah semua variabel independen atau bebas yang dimasukkan dalam model mempunyai pengaruh secara Bersama-sama terhadap variabel dependen/terikat. Pengujian kriteria ini adalah apabila Sig. lebih kecil dari 0,05, maka dapat dinyatakan bahwa model penelitian layak untuk digunakan sebagai model pengujian dalam penelitian. Berikut ini disajikan uji F dalam penelitian ini untuk model regresi pertama.

$$
\mathrm{DER}=\mathrm{k}+\mathrm{p} 1 \mathrm{ROE}+\mathrm{p} 2 \mathrm{DPR}+\mathrm{p} 3 \mathrm{SIZE}+\mathrm{e} 1
$$

Tabel 5. Hasil Uji Statistik F Model Regresi Pertama

\begin{tabular}{|ll|r|r|r|r|r|}
\hline \multicolumn{1}{|c|}{ ANOVA $^{\text {a }}$} \\
Model & & \multicolumn{1}{c|}{$\begin{array}{c}\text { Sum of } \\
\text { Squares }\end{array}$} & \multicolumn{1}{c|}{ df } & Mean Square & F & Sig. \\
\hline 1 & Regression & 18,884 & 3 & 6,295 & 44,213 &, $000^{\text {b }}$ \\
& Residual & 22,921 & 161 &, 142 & & \\
& Total & 41,805 & 164 & & & \\
\hline
\end{tabular}

a. Dependent Variable: DER

b. Predictors: (Constant), SIZE, ROE, DPR

Sumber: Data sekunder yang diolah SPSS 20, 2019

Berdasarkan Tabel 5 uji statistik $F$ model regresi pertama dapat dilihat bahwa nilai $\mathrm{F}_{\text {hitung }}$ sebesar 44,213 sedangkan $\mathrm{F}_{\text {tabel }} 2,6604\left(\mathrm{a}=5 \%\right.$ ) dengan nilai probabilitas 0,000. Maka nilai $\mathrm{F}_{\text {hitung }} 44,213$ lebih besar dari $\mathrm{F}_{\text {tabel }}$ 2,6604 dan diperkuat nilai probabilitas 0,000 lebih kecil dari $a=0,05$, jadi dapat disimpulkan bahwa koefisien regresi ROE, DPR dan SIZE secara simultan berpengaruh terhadap DER. Sedangkan hasil uji signifikansi F dalam penelitian ini untuk model regresi kedua sebagai berikut.

$$
L N \_P B V=k+p 4 R O E+p 5 D P R+p 6 S I Z E+p 7 D E R+e 2
$$

\section{Tabel 6. Hasil Uji Statistik F Model Regresi Pertama}

\section{ANOVA ${ }^{a}$}

\begin{tabular}{|ll|r|r|r|r|r|}
\hline Model & & \multicolumn{1}{c|}{$\begin{array}{c}\text { Sum of } \\
\text { Squares }\end{array}$} & df & Mean Square & \multicolumn{1}{c|}{ F } & Sig. \\
\hline 1 & Regression & 108,353 & 4 & 27,088 & 46,159 &, $000^{\mathrm{b}}$ \\
& Residual & 93,896 & 160 &, 587 & & \\
& Total & 202,249 & 164 & & & \\
\hline
\end{tabular}

a. Dependent Variable: LN_PBV

b. Predictors: (Constant), DER, SIZE, DPR, ROE

Sumber: Data sekunder yang diolah SPSS 20, 2019 
Berdasarkan Tabel 6 uji statistik F model kedua dapat dilihat bahwa nilai $F_{\text {hitung }}$ sebesar 46,159 sedangkan $F_{\text {tabel }} 2,4278(a=5 \%)$ dengan nilai probabilitas 0,000. Maka nilai $F_{\text {hitung }}$ sebesar 46,159 lebih besar dari $F_{\text {tabel }} 2,4278$ dan diperkuat nilai probabilitas 0,000 lebih kecil dari $\alpha=0,05$, jadi dapat disimpulkan bahwa koefisien regresi ROE, DPR, SIZE, dan DER secara simultan berpengaruh terhadap PBV.

\section{Uji Parsial (Uji t)}

Uji statistikt pada dasarnya menunjukkan seberapa jauh pengaruh satu variabel penjelas atau independen secara individual dalam menerangkan variasi variabel dependen. Untuk menginterpretasikan koefisien parameter variabel independen dapat digunakan unstandardizes coefficients. Kriteria Hasil pengujian adalah probability value (Sig)-t, apabila probability value (sig)-t lebih kecil dari 5\%, maka dapat dinyatakan bahwa variabel independen berpengaruh terhadap variabel dependen sehingga hipotesis yang diajukan dalam pengujian dapat diterima, apabila probability value (sig)-t lebih besar dari 5\%, maka dapat dinyatakan bahwa variabel tidak berpengaruh pada variabel dependen dan hipotesis yang diajukan adalah tidak diterima. Hasil uji t model regresi pertama dalam penelitian ini adalah sebagai berikut.

$$
\mathrm{DER}=-0,048+1,243 \mathrm{ROE}-0,083 \mathrm{DPR}+0,031 \mathrm{SIZE}+0,7403
$$

Tabel 7. Hasil Uji Statistik t Model Regresi Pertama

\begin{tabular}{|c|c|c|c|c|c|c|c|c|}
\hline \multicolumn{9}{|c|}{ Coefficients $^{a}$} \\
\hline \multirow{2}{*}{\multicolumn{2}{|c|}{ Model }} & \multicolumn{2}{|c|}{ Unstandardized Coefficients } & \multirow{2}{*}{$\begin{array}{c}\begin{array}{c}\text { Standardized } \\
\text { Coefficients }\end{array} \\
\text { Beta }\end{array}$} & \multirow[b]{2}{*}{$t$} & \multirow[b]{2}{*}{ Sig. } & \multicolumn{2}{|c|}{ Collinearity Statistics } \\
\hline & & $\mathrm{B}$ & Std. Error & & & & Tolerance & VIF \\
\hline \multirow[t]{4}{*}{1} & (Constant) &,- 480 & 486 & &,- 988 &, 325 & & \\
\hline & ROE & 1,243 & 121 &, 677 & 10,248 &, 000 &, 780 & 1,283 \\
\hline & DPR &,- 083 & , 107 &,- 052 &,- 776 & 439 &, 759 & 1,317 \\
\hline & SIZE &, 031 &, 017 & , 108 & 1,823 &, 070 &, 966 & 1,036 \\
\hline
\end{tabular}

a. Dependent Variable: DER

Sumber: Data sekunder yang diolah SPSS 20, 2019

Berdasarkan Tabel 7 dalam model regresi pertama penelitian ini diketeahui dengan tingkat signifikan 5\% diperoleh nilai $t_{\text {tabel }}$ sebesar 1,97481. Hasil uji model regresi pertama menunjukkan hasil sebagai berikut:

1. Konstanta sebesar - 0,480 menunjukkan bahwa apabila variabel ROE (profitabilitas), DPR (kebijakan dividen), dan SIZE (ukuran perusahaan) bernilai 0 atau tidak ada maka variabel DER (struktur modal) akan mengalami penurunan sebesar 0,480.

2. Variabel ROE (profitabilitas) menunjukkan nilai $t_{\text {hitung }}$ sebesar 10,248 lebih besar dari nilai $t_{\text {tabel }}$ sebesar 1,97481 dan signifikan sebesar 0,000 < 0,05, sehingga dapat disimpulkan bahwa H1 Diterima. Ini berarti variabel ROE (profitabilitas) secara statistik berpengaruh terhadap perubahan variabel DER 
(struktur modal). Perubahan variabel ROE (profitabilitas) mempunyai nilai koefisien regresi sebesar 1,243. Menunjukkan nilai koefisien regresi sebesar 1,243 dengan arah positif dapat diartikan bahwa ROE (profitabilitas) mempunyai pengaruh positif terhadap DER (struktur modal), atau ROE (profitabilitas) menunjukkan kenaikan maka akan mempengaruhi kenaikan DER (struktur modal).

3. Variabel DPR (kebijakan dividen) menunjukkan nilai $t_{\text {hitung }}$ sebesar - 0,776 lebih kecil dari nilai $t_{\text {tabel }}$ sebesar 1,97481 dan signifikan sebesar 0,439 > 0,05, sehingga dapat disimpulkan bahwa H2 Ditolak. Ini berarti variabel DPR (kebijakan dividen) secara statistik tidak berpengaruh terhadap DER (struktur modal). Perubahan variabel DPR (kebijakan dividen) mempunyai nilai koefisien regresi sebesar - 0,083. Menunjukkan nilai koefisien regresi sebesar - 0,083 dengan arah negatif dapat diartikan bahwa DPR (kebijakan dividen) mempunyai pengaruh negatif terhadap DER (struktur modal), atau DPR (kebijakan dividen) menunjukkan penurunan maka tidak akan mempengaruhi nilai DER (struktur modal).

4. Variabel SIZE (ukuran perusahaan) menunjukkan nilai $t_{\text {hitung }}$ sebesar 1,823 lebih kecil dari nilai $t_{\text {tabel }}$ sebesar 1,97481 dan signifikan sebesar 0,070 > 0,05, sehingga dapat disimpulkan bahwa H3 Ditolak. Ini berarti variabel SIZE (ukuran perusahaan) secara statistik tidak berpengaruh terhadap DER (struktur modal). Perubahan variabel SIZE (ukuran perusahaan) mempunyai nilai koefisien regresi sebesar 0,031 dengan arah positif dapat diartikan bahwa SIZE (ukuran perusahaan) mempunyai pengaruh positif terhadap DER (struktur modal), atau SIZE (ukuran perusahaan) menunjukkan kenaikan maka tidak akan mempengaruhi nilai DER (struktur modal).

Selanjutnya hasil uji signifikansi-t model regresi kedua dalam penelitian ini dapat dilihat sebagai berikut:

$$
\text { LN_PBV }=-4,268+3,318 R O E-0,032 D P R+0,168 S I Z E-0,598 D E R+0,6812
$$

\section{Tabel 8. Hasil Uji Statistik t Model Regresi Kedua}

\begin{tabular}{|c|c|c|c|c|c|c|c|c|}
\hline \multicolumn{9}{|c|}{ Coefficients $^{a}$} \\
\hline & & \multicolumn{2}{|c|}{ Unstandardized Coefficients } & $\begin{array}{c}\text { Standardized } \\
\text { Coefficients }\end{array}$ & \multirow[b]{2}{*}{$t$} & \multirow[b]{2}{*}{ Sig. } & \multicolumn{2}{|c|}{ Collinearity Statistics } \\
\hline \multicolumn{2}{|c|}{ Model } & $\mathrm{B}$ & Std. Error & Beta & & & Tolerance & VIF \\
\hline \multirow[t]{5}{*}{1} & (Constant) & $-4,268$ & 989 & & $-4,314$ &, 000 & & \\
\hline & ROE & 3,318 &, 317 &, 822 & 10,478 &, 000 & .472 & 2,120 \\
\hline & DPR &,- 032 &, 217 &,- 009 &,- 146 &, 884 &, 756 & 1,322 \\
\hline & SIZE &, 168 &, 035 & 268 & 4,841 &, 000 &, 946 & 1,057 \\
\hline & DER &,- 598 &, 160 &,- 272 & $-3,737$ &, 000 &, 548 & 1,824 \\
\hline
\end{tabular}

a. Dependent Variable: LN_PBV

Sumber: Data sekunder yang diolah SPSS 20, 2019

Berdasarkan Tabel 8 dalam model regresi kedua penelitian ini diketahui dengan tingkat signifikan 5\% diperoleh nilai $t_{\text {tabel }}$ sebesar 1,97490. Hasil uji model regresi pertama menunjukkan hasil sebagai berikut: 
1. Konstanta sebesar - 4,268 menunjukkan bahwa apabila variabel ROE (profitabilitas), DPR (kebijakan dividen), SIZE (ukuran perusahaan), dan DER (struktur modal) bernilai 0 atau tidak ada maka variabel PBV (nilai perusahaan) akan mengalami penurunan sebesar 4,268.

2. Variabel ROE (profitabilitas) menunjukkan nilai $t_{\text {hitung }}$ sebesar 10,478 lebih besar dari nilai $t_{\text {tabel }}$ sebesar 1,97490 dan signifikan sebesar 0,000 < 0,05, sehingga dapat disimpulkan bahwa H4 Diterima. Ini berarti variabel ROE (profitabilitas) secara statistik berpengaruh terhadap perubahan variabel PBV (nilai perusahaan). Perubahan variabel ROE (profitabilitas) mempunyai nilai koefisien regresi sebesar 3,318. Menunjukkan nilai koefisien regresi sebesar 3,318 dengan arah positif dapat diartikan bahwa ROE (profitabilitas) mempunyai pengaruh positif terhadap PBV (nilai perusahaan), atau ROE (profitabilitas) menunjukkan kenaikan maka akan mempengaruhi kenaikan PBV (nilai perusahaan).

3. Variabel DPR (kebijakan dividen) menunjukkan nilai $\mathrm{t}_{\text {hitung }}$ sebesar-0,146 lebih kecil dari nilai $\mathrm{t}_{\text {tabel }}$ sebesar 1,97490 dan signifikan sebesar 0,884 > 0,05, sehingga dapat disimpulkan bahwa H5 Ditolak. Ini berarti variabel DPR (kebijakan dividen) secara statistik tidak berpengaruh terhadap PBV (nilai perusahaan). Perubahan variabel DPR (kebijakan dividen) mempunyai nilai koefisien regresi sebesar - 0,032. Menunjukkan nilai koefisien regresi sebesar - 0,032 dengan arah negatif dapat diartikan bahwa DPR (kebijakan dividen) mempunyai pengaruh negatif terhadap PBV (nilai perusahaan), atau DPR (kebijakan dividen) menunjukkan penurunan maka tidak akan mempengaruhi nilai PBV (nilai perusahaan).

4. Variabel SIZE (ukuran perusahaan) menunjukkan nilai $t_{\text {hitung }}$ sebesar 4,841 lebih besar dari nilai tabel $_{\text {sebesar }}$ 1,97490 dan signifikan sebesar 0,000 < 0,05, sehingga dapat disimpulkan bahwa H6 Diterima. Ini berarti variabel SIZE (ukuran perusahaan) secara statistik berpengaruh terhadap perubahan variabel PBV (nilai perusahaan). Perubahan variabel SIZE (ukuran perusahaan) mempunyai nilai koefisien regresi sebesar 0,168 dengan arah positif dapat diartikan bahwa SIZE (ukuran perusahaan) mempunyai pengaruh positif terhadap PBV (nilai perusahaan), atau SIZE (ukuran perusahaan) menunjukkan kenaikan maka akan mempengaruhi kenaikan PBV (nilai perusahaan).

5. Variabel DER (struktur modal) menunjukkan nilai $t_{\text {hitung }}$ sebesar $-3,737$ lebih kecil dari nilai $t_{\text {tabel }}$ sebesar 1,97490 dan signifikan sebesar 0,000 < 0,05, sehingga dapat disimpulkan bahwa H7 Diterima. Ini berarti variabel DER (struktur modal) secara statistik berpengaruh terhadap perubahan PBV (nilai perusahaan). Perubahan variabel DER (struktur modal) mempunyai nilai koefisien regresi sebesar - 0,598 dengan arah negatif dapat diartikan bahwa DER (struktur modal) mempunyai pengaruh negatif terhadap PBV (nilai perusahaan), atau DER (struktur modal) menunjukkan kenaikan maka akan mempengaruhi kenaikan PBV (nilai perusahaan).

\section{Analisis Jalur (Path Analysis)}

Analisis jalur digunakan untuk menganalisa suatu pola hubungan antara variabel dengan tujuan untuk mengetahui pengaruh langsung maupun tidak langsung seperangkat bebas (eksogen) terhadap variabel terikat (endogen). Berikut ini dapat dilihat dalam diagram jalur setelah diketahui koefisien masing-masing variabel di dalam model regresi pertama dan kedua atau full model: 


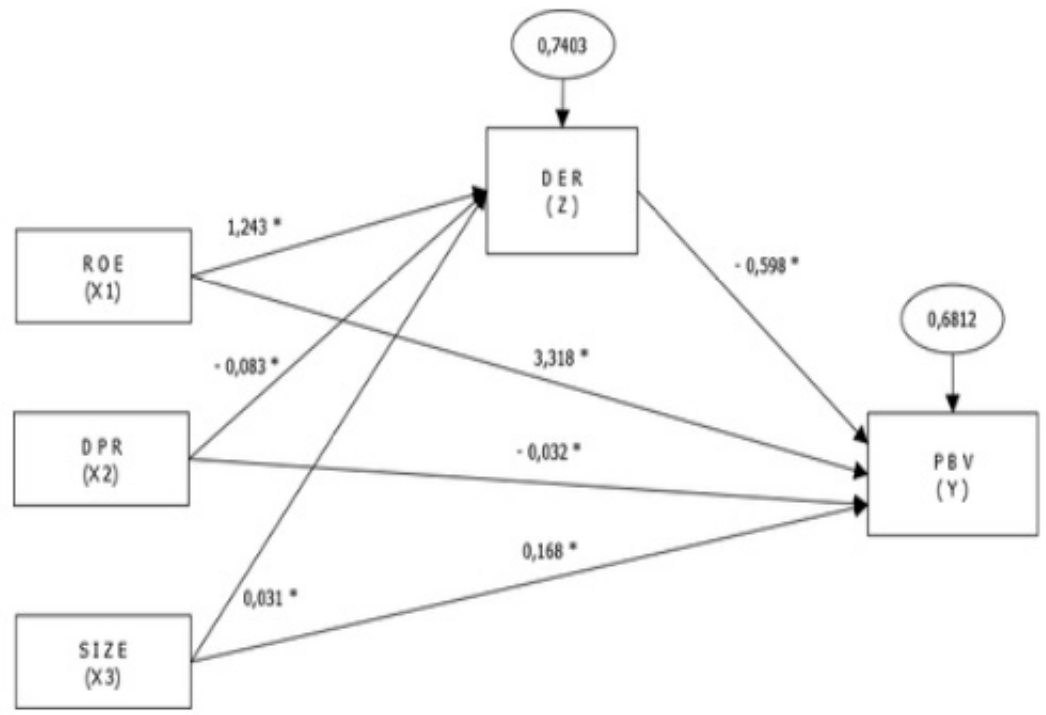

Gambar 1. Diagram Jalur (Path Diagram) Full Model

$$
\begin{gathered}
\text { DER }=-0,048+1,243 \mathrm{ROE}-0,083 \mathrm{DPR}+0,031 \mathrm{SIZE}+0,7403 \\
\mathrm{LN} \_\mathrm{PBV}=-4,268+3,318 \mathrm{ROE}-0,032 \mathrm{DPR}+0,168 \mathrm{SIZE}-0,598 \mathrm{DER}+0,6812
\end{gathered}
$$

Hasil analisis jalur (path analysis) menunjukkan bahwa ada koefisien jalur yang tidak signifikan yaitu variabel DPR ke DER (nilai jalur p2); variabel SIZE ke DER (nilai jalur p3); dan variabel DPR ke PBV (nilai jalur P5).

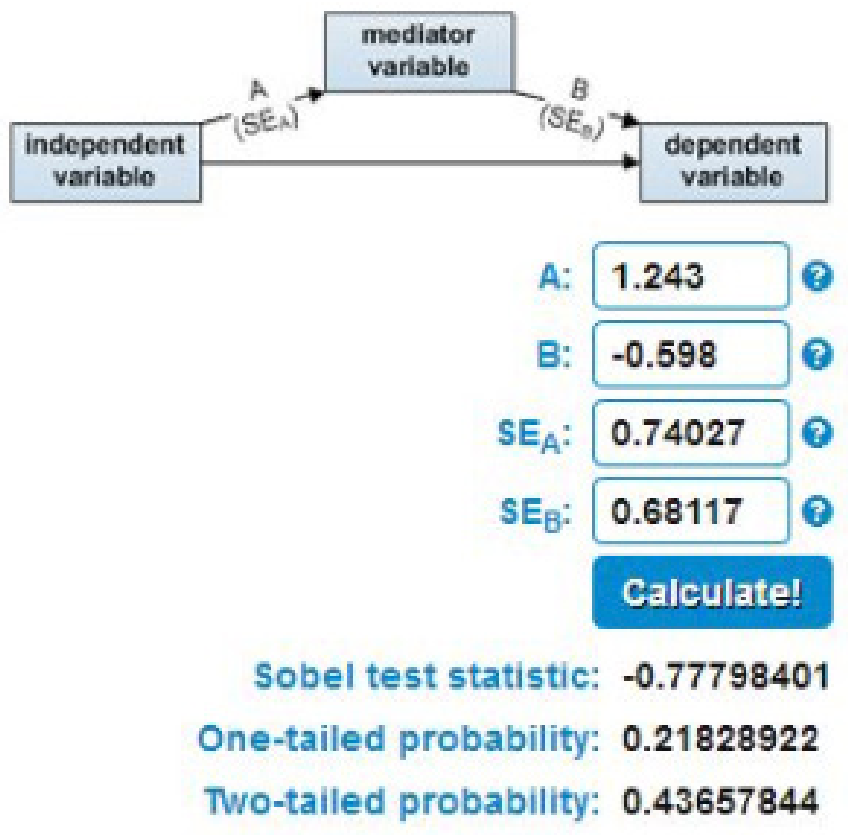

Gambar 2. Sobel Test 
Berdasarkan Tabel 4.19 menjelaskan pengaruh langsung dan pengaruh tidak langsung antar variabel dalam penelitian. Pengaruh langsung ROE (X1) terhadap PBV (Y) sebesar 3,318; dan pengaruh ROE (X1) melalui variabel intervening DER $(Z)$ terhadap PBV $(Y)$ sebesar $1,243 \times(-0,598)=-0,743$. Sehingga total pengaruh (korelas ROE ke DER) adalah 3,318 + (- 0,743) =2,575. Untuk menentukan signifikan atau tidaknya besar nilai pengaruh mediasi yang ditunjukkan oleh perkalian koefisien (p4 x p7), maka akan di uji dengan Sobel Test yang ditunjukkan gambar 2.

Berdasarkan hasil output sobel test calculator pada gambar 4.4 dapat dilihat bahwa nilai koefisien twotailed probability profitabilitas (ROE) sebesar 0,437. variabel struktur modal (DER) tidak dapat memediasi hubungan antar variabel profitabilitas (ROE) terhadap nilai perusahaan (PBV). H8 Ditolak.

Berikut ini adalah ringkasan hasil analisis dari model regresi pertama sampai kedua.

Tabel 11. Ringkasan Hasil Analisis

\begin{tabular}{|c|c|c|c|c|}
\hline Hipotesis & Koefisien & Nilai $p$ & Hasil & Hasil \\
\hline $\mathrm{H} 1: \mathrm{ROE} \otimes \mathrm{DER}$ & 1,243 & 0,000 & H1 Diterima & $\begin{array}{l}\text { Berpengaruh positif dan } \\
\text { signifikan }\end{array}$ \\
\hline $\mathrm{H} 2: \mathrm{DPR} \otimes \mathrm{DER}$ & $-0,083$ & 0,439 & H2 Ditolak & Tidak berpengaruh \\
\hline H3 : SIZE $\bigotimes D E R$ & 0,031 & 0,070 & H3 Ditolak & Tidak berpengaruh \\
\hline $\mathrm{H} 4$ : ROE $\otimes \mathrm{PBV}$ & 3,318 & 0,000 & H4 Diterima & $\begin{array}{l}\text { Berpengaruh positif dan } \\
\text { signifikan }\end{array}$ \\
\hline $\mathrm{H} 5: \mathrm{DPR} \otimes \mathrm{PBV}$ & $-0,032$ & 0,884 & H5 Ditolak & Tidak berpengaruh \\
\hline H6 : SIZE $\otimes P B V$ & 0,168 & 0,000 & H6 Diterima & $\begin{array}{l}\text { Berpengaruh positif dan } \\
\text { signifikan }\end{array}$ \\
\hline $\mathrm{H} 7: \mathrm{DER} \otimes \mathrm{PBV}$ & $-0,598$ & 0,000 & H7 Diterima & $\begin{array}{l}\text { Berpengaruh negatif dan } \\
\text { signifikan }\end{array}$ \\
\hline $\mathrm{H} 8:$ ROE $\triangle \mathrm{DER} \otimes \mathrm{PBV}$ & 2,575 & 0,437 & H8 Ditolak & Tidak berpengaruh \\
\hline $\mathrm{H} 9: \mathrm{DPR} \otimes \mathrm{DER} \otimes \mathrm{PBV}$ & \multicolumn{4}{|c|}{ Dieleminasi, karena variabel independen ke intervening tidak signifikan } \\
\hline $\mathrm{H} 10:$ SIZE $\triangle D E R \otimes P B V$ & \multicolumn{4}{|c|}{ Dieleminasi, karena variabel independen ke intervening tidak signifikan } \\
\hline
\end{tabular}

Sumber: Data sekunder yang diolah SPSS 20, 2019

\section{Pembahasan}

Berdasarkan data pengujian yang telah dilakukan, maka akan menjelaskan lebih detail pada pembahasan di hasil uji hipotesis. adapun pembahasan dari setiap hipotesis dalam penelitian ini adalah:

\section{Pengaruh Profitabilitas terhadap Struktur Modal}

Hasil penelitian menunjukkan bahwa profitabilitas (ROE) berpengaruh positif dan signifikan terhadap struktur modal (DER). Hasil ini diperkuat dalam Tabel 4.16 bahwa profitabilitas mempunyai nilai signifikansi 0,000 yang lebih kecil dari 0,05 dan koefisien regresi sebesar 1,243 dengan arah positif, sehingga dapat disimpulkan bahwa profitabilitas (ROE) mempunyai pengaruh positif terhadap struktur modal (DER).

Profitabilitas menurut (Utari, 2014, p. 63) merupakan kemampuan manajemen untuk memperoleh laba. Laba terdiri dari laba kotor, laba operasi, laba bersih. Semakin tinggi profitabilitas, maka akan semakin tinggi 
pula struktur modalnya. Semakin tinggi profitabilitas, maka semakin besar laba ditahan yang akan diimbangi dengan hutang yang lebih tinggi karena peluang perusahaan dianggap sangat bagus. Oleh karena itu, H1 yang menyatakan bahwa profitabilitas (ROE) berpengaruh terhadap struktur modal (DER) diterima.

Hal ini sejalan dengan penelitian yang dilakukan oleh (Khoirianto, 2016) yang menyatakan arah positif mengandung arti bahwa semakin besar profitabilitas maka semakin besar pula struktur modal perusahaan. Sedangkan penelitian yang dilakukan oleh (Junita, 2014) yang menyatakan besarnya tidak terdapat pengaruh antara profitabilitas dengan struktur modal.

\section{Pengaruh Kebijakan Dividen terhadap Struktur Modal}

Hasil penelitian menunjukkan bahwa kebijakan dividen (DPR) tidak berpengaruh terhadap struktur modal (DER). Hasil ini diperkuat dalam Tabel 4.16 bahwa kebijakan dividen mempunyai nilai signifikansi 0,439 yang lebih besar dari 0,05 dan koefisien regresi sebesar - 0,083 dengan arah negatif, sehingga dapat disimpulkan bahwa kebijakan dividen (DPR) tidak berpengaruh terhadap struktur modal (DER).

Kebijakan dividen yaitu besarnya laba yang dibagikan kepada pemegang saham pada akhir tahun yang juga akan mencerminkan besarnya laba yang akan ditanamkan pada laba ditahan pada akhir tahun (Walsh, 2004, p. 152). Pembayaran dividen muncul sebagai pengganti hutang di dalam struktur modal untuk mengawasi perilaku manajer. Apabila dividend payout ratio tinggi maka jumlah laba bersih yang akan ditahan sebagai laba ditahan akan berkurang sehingga sumber pembiayaan internal perusahaan akan semakin kecil dan perusahaan akan mencari sumber dana yang berasal dari eksternal. Oleh karena itu, H2 yang menyatakan bahwa kebijakan dividen (DPR) berpengaruh terhadap struktur modal (DER) ditolak.

Hal ini sejalan dengan penelitian yang dilakukan oleh (Nainggolan, 2017) yang menyatakan bahwa kebijakan dividen berpengaruh negatif tetapi tidak signifikan terhadap struktur modal. Sedangkan penelitian yang dilakukan oleh (Khoirianto, 2016) menyatakan bahwa kebijakan dividen berpengaruh negatif dan signifikan terhadap struktur modal.

\section{Pengaruh Ukuran Perusahaan terhadap Struktur Modal}

Hasil penelitian menunjukkan bahwa ukuran perusahaan (SIZE) tidak berpengaruh terhadap struktur modal (DER). Hasil ini diperkuat dalam Tabel 4.16 bahwa ukuran perusahaan mempunyai nilai signifikansi 0,070 yang lebih besar dari 0,05 dan koefisien regresi sebesar 0,031 dengan arah positif, sehingga dapat disimpulkan bahwa ukuran perusahaan (SIZE) tidak berpengaruh terhadap struktur modal (DER).

Ukuran perusahaan menggambarkan besar kecilnya suatu perusahaan yang ditunjukkan pada total aktiva, jumlah penjualan, rata-rata total aktiva (Riyanto, 2008). Ukuran perusahaan yang besar tidak akan meningkatkan atau menaikkan struktur modal dari perusahaan karena ukuran perusahaan yang besar menunjukkan bahwa perusahaan memiliki sumber dana internal atau laba ditahan yang besar, sehingga perusahaan mampu untuk membiayai investasi dengan dana yang dihimpunnya tersebut. Oleh karena itu, H3 yang menyatakan bahwa ukuran perusahaan (SIZE) berpengaruh terhadap struktur modal (DER) ditolak.

Hal ini sejalan dengan penelitian yang dilakukan oleh (Junita, 2014) yang menyatakan bahwa ukuran perusahaan tidak berpengaruh terhadap struktur modal. Sedangkan penelitian yang dilakukan oleh 
(Hermuningsih, 2013) yang menyatakan SIZE berpengaruh positif dan signifikan terhadap struktur modal. hal ini dapat dijelaskan bahwa besar kecilnya perusahaan sangat berpengaruh terhadap keputusan penggunaan hutang dalam struktur modal, terutama berkaitan dengan kemampuan memperoleh pinjaman.

\section{Pengaruh Profitabilitas terhadap Nilai Perusahaan}

Hasil penelitian menunjukkan bahwa profitabilitas (ROE) berpengaruh positif dan signifikan terhadap nilai perusahaan (PBV). Hasil ini diperkuat dalam Tabel 4.17 bahwa profitabilitas mempunyai nilai signifikansi 0,000 yang lebih kecil dari 0,05 dan koefisien regresi sebesar 3,318 dengan arah positif, sehingga dapat disimpulkan bahwa profitabilitas (ROE) mempunyai pengaruh positif terhadap nilai perusahaan (PBV).

Profitabilitas yang dapat di ukur dengan Return On Equity (ROE). Return on equity adalah rasio yang mengukur banyak keuntungan yang menjadi hak pemilik modal sendiri. ROE mencerminkan tingkat pengembalian investasi bagi para pemegang saham. Semakin tinggi ROE merupakan semakin efisiensi perusahaan menggunakan modal sendiri untuk menghasilkan laba atau keuntungan bersih (Suffah \& Riduwan, 2016). Oleh karena itu, H4 yang menyatakan bahwa profitabilitas (ROE) berpengaruh terhadap nilai perusahaan (PBV) diterima.

Hal ini sejalan dengan penelitian yang dilakukan oleh (Khoirianto, 2016) yang menyatakan bahwa profitabilitas berpengaruh positif dan signifikan terhadap nilai perusahaan. Yang artinya ketika profitabilitas naik, maka nilai perusahaan juga akan naik, atau sebaliknya. Sedangkan penelitian yang dilakukan oleh (Asmidar, 2015) yang menyatakan bahwa profitabilitas tidak berpengaruh terhadap nilai perusahaan.

\section{Pengaruh Kebijakan Dividen terhadap Nilai Perusahaan}

Hasil penelitian menunjukkan bahwa kebijakan dividen (DPR) tidak berpengaruh terhadap nilai perusahaan (PBV). Hasil ini diperkuat dalam Tabel 4.17 bahwa ukuran perusahaan mempunyai nilai signifikansi 0,884 yang lebih besar dari 0,05 dan koefisien regresi sebesar - 0,032 dengan arah negatif, sehingga dapat disimpulkan bahwa kebijakan dividen (DPR) tidak berpengaruh terhadap nilai perusahaan (PBV).

Dividen merupakan pembagian laba kepada para pemegang saham oleh perusahaan. Dividen harus sesuai dengan kebutuhan perusahaan maupun kebutuhan para pemegang saham. Dengan membayarkan dividen secara wajar, maka perusahaan dapat membantu menarik para investor untuk mencari dividend dan hal ini dapat membantu memelihara nilai perusahaan. Hasil yang diharapkan oleh para investor adalah berupa dividend dan kenaikan nilai saham. Oleh karena itu, H5 yang menyatakan bahwa kebijakan dividen (DPR) berpengaruh terhadap nilai perusahaan (PBV) ditolak.

Hal ini sejalan dengan penelitian yang dilakukan oleh (Khoirianto, 2016) bahwa kebijakan dividen (DPR) tidak berpengaruh terhadap nilai perusahaan. Penelitian ini tidak konsisten dengan penelitian yang dilakukan oleh (Asmidar, 2015) yang menyatakan bahwa kebijakan dividen berpengaruh terhadap nilai perusahaan.

\section{Pengaruh Ukuran Perusahaan terhadap Nilai Perusahaan}

Hasil penelitian menunjukkan bahwa ukuran perusahaan (SIZE) berpengaruh positif dan signifikan terhadap nilai perusahaan (PBV). Hasil ini diperkuat dalam Tabel 4.17 bahwa ukuran perusahaan mempunyai 
nilai signifikansi 0,000 yang lebih kecil dari 0,05 dan koefisien regresi sebesar 0,168 dengan arah positif, sehingga dapat disimpulkan bahwa ukuran perusahaan (SIZE) mempunyai pengaruh positif terhadap nilai perusahaan (PBV).

Ukuran perusahaan merupakan besar maupun kecilnya suatu perusahaan yang dapat dilihat melalui besarnya ekuitas, penjualan maupun total aktiva perusahaan. Total aktiva perusahaan yang semakin besar dapat menggambarkan bahwa perusahaan tersebut sudah mencapai tahap kedewasaannya. Berdasarkan pengujian dari (Asmidar, 2015; Putri, 2014) menyatakan bahwa ukuran perusahaan memiliki pengaruh yang signifikan terhadap nilai perusahaan. Perusahaan akan didorong untuk selalu meningkatkan ukuran perusahaan dan pengelolaan perusahaan dengan baik sehingga akan meningkatkan nilai perusahaan. Oleh karena itu, $\mathrm{H} 6$ yang menyatakan bahwa ukuran perusahaan (SIZE) berpengaruh terhadap nilai perusahaan (PBV) diterima.

Hal ini sejalan dengan penelitian yang dilakukan oleh (Putri, 2014) yang menyatakan bahwa variabel SIZE dapat digunakan sebagai alat untuk menilai PBV pada perusahaan manufaktur. Penelitian ini tidak konsisten dengan penelitian yang dilakukan oleh Suffah dan Riduwan (2016) yang menyatakan bahwa ukuran perusahaan tidak berpengaruh signifikan pada nilai perusahaan.

\section{Pengaruh Struktur Modal terhadap Nilai Perusahaan}

Hasil penelitian menunjukkan bahwa struktur modal (DER) berpengaruh negatif dan signifikan terhadap nilai perusahaan (PBV). Hasil ini diperkuat dalam Tabel 4.17 bahwa struktur modal mempunyai nilai signifikansi 0,000 yang lebih kecil dari 0,05 dan koefisien regresi sebesar - 0,598 dengan arah negatif, sehingga dapat disimpulkan bahwa struktur modal (DER) mempunyai pengaruh negatif terhadap nilai perusahaan (PBV).

Penambahan hutang akan meningkatkan tingkat rasio atas arus pendapatan perusahaan, yang mana pendapatan dipengaruhi faktor eksternal sedangkan hutang menimbulkan beban tetap tanpa memperdulikan besarnya pendapatan. Semakin tinggi struktur modal maka nilai perusahaan yang tercermin pada harga saham perusahaan semakin tinggi. Oleh karena itu, $\mathrm{H} 7$ yang menyatakan bahwa struktur modal (DER) berpengaruh terhadap nilai perusahaan (PBV) diterima.

Hal ini sejalan dengan penelitian yang dilakukan oleh (Khoirianto, 2016) yang menyatakan bahwa struktur modal berpengaruh negatif dan signifikan terhadap nilai perusahaan. Yang artinya pada tingkat hutang rendah nilai perusahaan akan menurun. Penelitian ini tidak konsisten dengan penelitian yang dilakukan oleh (Putri, 2014) yang menyatakan bahwa Dept to Equity Ratio tidak berpengaruh signifikan terhadap PBV pada perusahaan manufaktur yang terdapat di Bursa Efek Indonesia pada periode 2009-2012.

\section{Pengaruh Profitabilitas terhadap Nilai Perusahaan melalui Struktur Modal}

Hasil analisis data penelitian yang telah diuji membuktikan bahwa struktur modal (DER) sebagai variabel intervening tidak dapat memediasi pengaruh profitabilitas (ROE) terhadap nilai perusahaan (PBV). Dalam hasil penelitian analisis jalur (path analysis) menunjukkan bahwa profitabilitas (ROE) mempunyai nilai koefisien standardized beta profitabilitas (ROE) dalam Tabel 4.18 yaitu sebesar 1,243 merupakan nilai jalur p1 dengan nilai signifikansi $0,000<0,05$, dan nilai koefisien standardized beta profitabilitas (ROE) dalam Tabel 4.19 yaitu 
sebesar 3,318 merupakan nilai jalur p4 dengan nilai signifikansi 0,000 <0,05, dan nilai koefisien standardized beta struktur modal (DER) dalam Tabel 4.19 yaitu sebesar - 0,598 merupakan nilai jalur p7 dengan nilai signifikansi 0,000 $<0,05$.

Hasil dari gambar 4.2 terdapat pengaruh langsung profitabilitas (ROE) terhadap nilai perusahaan (PBV) sebesar 1,243 dengan pengaruh tidak langsung profitabilitas terhadap nilai perusahaan yang dimediasi oleh struktur modal yang dihitung dengan sobel test berdasarkan gambar 4.4 menunjukkan hasil 0,437 yang lebih besar dari 0,05 yang berarti bahwa variabel struktur modal (DER) tidak dapat memediasi hubungan antara variabel profitabilitas (ROE) dengan nilai perusahaan (PBV). Hasil penelitian tersebut menunjukkan bahwa $\mathrm{H} 8$ ditolak.

Struktur modal merupakan perimbangan jumlah utang jangka pendek yang bersifat permanen, utang jangka panjang, saham prefer dan saham biasa. Berdasarkan hasil pengolahan data sampel bahwa nilai rata-rata profitabilitas (ROE) perusahaan sampel adalah 5,6473. Dari 165 sampel yang diteliti menunjukkan bahwa 29,2\% perusahaan yang mempunyai nilai dibawah rata-rata profitabilitas (ROE), sedangkan sisanya 70.8\% perusahaan yang mempunyai nilai diatas rata-rata profitabilitas (ROE). Hal ini mengidentifikasikan bahwa perusahaan yang tidak berhasil memperoleh laba yang besar maka manajer perusahaan tidak dapat mengelola laba melalui struktur modal (DER), yang berdampak pada kinerja perusahaan dan nilai perusahaan akan menurun.

Hal ini sejalan dengan penelitian yang dilakukan (Wulandari, 2013) yang menyatakan bahwa struktur modal tidak dapat memediasi hubungan profitabilitas terhadap nilai perusahaan.

\section{Pengaruh Kebijakan Dividen terhadap Nilai Perusahaan melalui Struktur Modal}

Hasil analisis data penelitian yang telah diuji membuktikan bahwa struktur modal (DER) sebagai variabel intervening tidak dapat memediasi pengaruh kebijakan dividen (DPR) terhadap nilai perusahaan (PBV). Dari hasil penelitian analisis jalur (path analysis) menunjukkan bahwa kebijakan dividen (DPR) mempunyai nilai koefisien standardized beta kebijakan dividen (DPR) dalam Tabel 4.18 yaitu sebesar - 0,083 merupakan nilai jalur p2 dengan nilai signifikansi 0,439 >0,05, dan nilai koefisien standardized beta kebijakan dividen (DPR) dalam Tabel 4.19 yaitu sebesar - 0,032 merupakan nilai jalur p5 dengan nilai signifikansi 0,884 >0,05, dan nilai koefisien standardized beta struktur modal (DER) dalam Tabel 4.19 yaitu sebesar - 0,598 merupakan nilai jalur p7 dengan nilai signifikansi 0,000 $<0,05$.

Hasil dari gambar 4.2 terdapat pengaruh langsung kebijakan dividen (DPR) terhadap nilai perusahaan (PBV) sebesar - 0,083 dengan pengaruh tidak langsung kebijakan dividen terhadap nilai perusahaan yang dimediasi oleh struktur modal yang tidak dapat diuji karena struktur modal sebagai variabel intervening tidak signifikan terhadap variabel kebijakan dividen, yang berarti tidak dapat memediasi hubungan kebijakan dividen terhadap nilai perusahaan. Dalam penelitian ini struktur modal (DER) bukan merupakan variabel intervening yang tepat karena tidak memiliki pengaruh terhadap kebijakan dividen (DPR). Oleh karena itu, H9 yang menyatakan kebijakan dividen (DPR) berpengaruh terhadap nilai perusahaan (PBV) malalui struktur modal (DER) tidak bisa diuji dan hipotesis ini dieleminasi. 


\section{Pengaruh Ukuran Perusahaan terhadap Nilai Perusahaan melaui Struktur Modal}

Hasil analisis data penelitian yang telah telah diuji membuktikan bahwa struktur modal (DER) sebagai variabel intervening tidak dapat memediasi pengaruh ukuran perusahaan (SIZE) terhadap nilai perusahaan (PBV). Dari hasil penelitian analisis jalur (path analysis) menunjukkan bahwa ukuran perusahaan (SIZE) mempunyai nilai koefisien standardized beta ukuran perusahaan (SIZE) dalam Tabel 4.18 yaitu sebesar 0,031 merupakan nilai jalur p3 dengan nilai signifikansi 0,070 >0,05, dan nilai koefisien standardized beta ukuran perusahaan (SIZE) dalam Tabel 4.19 yaitu sebesar 0,168 merupakan nilai jalur p6 dengan nilai signifikansi $0,000<0,05$, dan nilai koefisien standardized beta struktur modal (DER) dalam Tabel 4.19 yaitu sebesar - 0,598 merupakan nilai jalur p7 dengan nilai signifikansi 0,000 $<0,05$.

Hasil dari gambar 4.2 terdapat pengaruh langsung ukuran perusahaan (SIZE) terhadap nilai perusahaan (PBV) sebesar 0,031 dengan pengaruh tidak langsung ukuran perusahaan terhadap nilai perusahaan yang dimediasi oleh struktur modal yang tidak dapat diuji karena struktur modal sebagai variabel intervening tidak signifikan terhadap variabel ukuran perusahaan, yang berarti tidak dapat memediasi hubungan ukuran perusahaan terhadap nilai perusahaan. Dalam penelitian ini struktur modal (DER) bukan merupakan variabel intervening yang tepat karena tidak memiliki pengaruh terhadap ukuran perusahaan (SIZE). Oleh karena itu, H10 yang menyatakan ukuran perusahaan (SIZE) berpengaruh terhadap nilai perusahaan (PBV) malalui struktur modal (DER) tidak bisa diuji dan hipotesis ini dieleminasi.

\section{KESUMPULAN DAN SARAN}

Berdasarkan hasil analisis dan pembahasan yang telah dijelaskan mengenai Pengaruh Profitabilitas, Kebijakan Dividend an Ukuran Perusahaan Terhadap Nilai Perusahaan Dengan Struktur Modal Sebagai Variabel Intervening (Studi pada Perusahaan Manufaktur Yang Listing Di Bursa Efek Indonesia Periode 20122016), dapat disimpulkan bahwa struktur model (DER) tidak mampu memediasi peran profitabilitas (ROE) terhadap nilai perusahaan (PBV). Adapun kebijakan dividen (DPR) dan ukuran perusahaan tidak berimplikasi secara langsung pada nilai perusahaan, melainkan melalui kebijakan dividen sebagai perantara. Penelitian ini menemukan bahwa ada pengaruh profitabilitas, kebijakan dividen, dan ukuran perusahaan terhadap nilai perusahaan melalui struktur modal sebagai variabel intervening.

\section{Saran}

Berdasarkan kesimpulan yang dijelaskan, maka dapat diberikan beberapa saran sebagai berikut:

1. Bagi Perusahaan

Berdasarkan hasil penelitian, pihak perusahaan hendaknya meningkatkan lagi nilai perusahaan sehingga investor dapat berinvestasi pada perusahaan. Dengan profitabilitas yang tinggi juga menjadi nilai tambah tersendiri bagi investor. Oleh karena itu, pihak perusahaan harus berupaya meningkatkan profitabilitas dan nilai perusahaan dari tahun ketahun.

2. Bagi Investor

Berdasarkan hasil penelitian, secara simultan terdapat variabel profitabilitas, kebijakan dividen, ukuran perusahaan terhadap nilai perusahaan melalui struktur modal. Oleh karena itu, investor disarankan untuk 
memperhatikan faktor profitabilitas, kebijakan dividen, ukuran perusahaan dan nilai perusahaan tersebut sehingga tujuan investor dapat tercapai. Hal tersebut jadi pertimbangan agar memberikan tingkat keuntungan yang maksimal.

\section{Keterbatasan Penelitian}

Penelitian ini masih memiliki beberaapa keterbatasan, keterbatasan penelitian ini adalah:

1. $R^{2}$ dalam variabel struktur modal sebesar 0,441 yang berarti $44,1 \%$ yang dipengaruhi oleh variabel profitabilitas, kebijakan dividend dan ukuran perusahaan, dan sisanya 55,9\% dipengaruhi variabel lain.

2. $R^{2}$ dalam variabel nilai perusahaan sebesar 0,524 yang berarti $52,4 \%$ yang dipengaruhi oleh variabel profitabilitas, kebijakan dividend, ukuran perusahaan dan struktur modal, dan sisanya 47,6\% dipengaruhi variabel lain.

3. Penelitian ini hanya terbatas pada industry manufaktur di antara industri lain yang listing di BEl periode 2012-2016.

\section{Agenda Penelitian Selanjutnya}

Berdasarkan keterbatasan penelitian di atas, maka peneliti ingin memberi masukan untuk penelitian selanjutnya sebagai berikut:

1. Penelitian selanjutnya dapat memasukkan variabel lain seperti likuiditas, resiko perusahaan, struktur aktiva, leverage dll yang berhubungan dengan nilai perusahaan melalui struktur modal.

2. Dalam penelitian selanjutnya dapat melakukan penelitian dengan meneliti sektor lain yang terdaftar di BEI.

\section{DAFTAR PUSTAKA}

Asmidar. (2015). Pengaruh Ukuran Perusahaan, Profitabilitas, Keputusan Investasi, Keputusan Pendanaan dan Kebijakan Dividen terhadap Nilai Perusahaan (Pada Perusahaan Manufaktur yang Terdaftar di Bursa Efek Indonesia Tahun 2010-2014). Universitas Maritim Raja Ali Haji.

Brigham, \& Houston. (2011). Dasar-dasar Manajemen Keuangan. Jakarta: Salemba Empat.

Copeland, T., \& Weston, F. (1992). Managerial Finance Eigth Edition. Jakarta: Penerbit Erlangga.

Farikhah, N. (2015). Pengaruh Kebijakan Dividen, Keputusan Investasi, Profitabilitas, Kebijakan Hutang, dan Ukuran Perusahaan Terhadap Nilai Perusahaan (Studi pada Perusahaan Manufaktur yang Listing di Bei 2011-2014). Universitas Semarang.

Ghozali, I. (2014). Ekonometrika Teori, Konsep, dan Aplikasi dengan IBM SPSS 22. Semarang: Badan Penerbit Universitas Diponegoro. Retrieved from https://scholar.google.co.id/citations?user=kbmkIQQAAAAJ\&hl =en\#d=gs_md_cita-d\&u=\%2Fcitations\%3Fview_op\%3Dview_citation\%26hl\%3Den\%26user\%3Dkbmk IQQAAAAJ\%26citation_for_view\%3DkbmkIQQAAAAJ\%3ASIv7DqKytYAC\%26tzom\%3D-420

Hermuningsih, S. (2013). Profitability, Growth Opportunity, Capital Structure, and the Firm Value. Bulletin of Monetary, Economics, and Banking, 115-135. https://doi.org/10.21098/bemp.v16i2.440 
Junita, et al. (2014). Pengaruh Profitabilitas, Pertumbuhan Aset, Operating Leverage, dan Ukuran Perusahaan terhadap Struktur Modal Studi Empiris pada Perusahaan Food and Beverages yang Terdafatr Di Bursa Efek Indonesia Periode 2010-2012.

Khoirianto, R. (2016). Pengaruh Profitabilitas dan Kebijakan Dividen terhadap Nilai Perusahaan dengan Struktur Modal sebagai Variabel Intervening (Studi pada Perusahaan Manufaktur yang Listing Di Bursa Efek Indonesia Periode 2009-2012). Akuntabilitas Jurnal IImiah IImu-IImu Ekonomi, 9(1).

Mardiyati, et al. (2012). Pengaruh Kebijakan Dividen, Kebijakan Hutang dan Profitabilitas terhadap Nilai Perusahaan Manufaktur yang Terdaftar Di Bursa Efek Indonesia (BEI) Periode 2005-2010. Jurnal Riset Manajemen Sains Indonesia, 3(1).

Meidiawati, \& Mildawati. (2016). Pengaruh Size, Growth, Profitabilitas, Struktur Modal, Kebijakan Dividen terhadap Nilai Perusahaan. Jurnal Ilmu Dan Riset Akuntansi, 5(2).

Nainggolan, M. V. (2017). Pengaruh Kebijakan Dividen, Profitabilitas, Ukuran Perusahaan, Resiko Bisnis, Cash Holding, Kontrol Kepemilikan, dan Non Debt Tax Shield terhadap Struktur Modal pada Perusahaan Manufaktur yang Terdaftar Di Bursa Efek Indonesia (Periode 2011-2014). JOM Fekom, 4(1).

Nofrita, R. (2013). Pengaruh Profitabilitas terhadap Nilai Perusahaan dengan Kebijakan Deviden sebgai Variabel Intervening (Studi Empiris pada Perusahaan Manufaktur yang Terdaftar di BEI). Universitas Negeri Padang.

Pradana, R. Y. (2015). Keterkaitan Profitabilitas, Dividend Payout Ratio dan Risiko Bisnis pada Struktur Modal (Studi Empiris Perusahaan Manufaktur 2011-2014). Universitas Dian Nuswantoro.

Pribadi, A. S., \& Sampurno, R. D. (2012). Analisis Pengaruh Cash Position, Firm Size, Growth Opportunity, Ownership, dan Return on Asset terhadap Dividend Payout Ratio. Diponegoro Journal of Management, $1(1)$.

Putri, S. M. (2014). Pengaruh Dividend Payout Ratio (DPR), Debt Equity Ratio (DER), Return On Asset (ROA), dan Size Perusahaan terhadap Nilai Perusahaan pada Perusahaan Manufaktur yang Terdaftar Di Bursa Efek Indonesia (BEI) Periode 2009-2012. E-Jurnal Universitas Maritim Raja Ali Haji.

Riyanto, B. (2008). Dasar-dasar Pembelanjaan Perusahaan. Yogyakarta: BPFE Yogyakarta.

Rubiyani, \& Yuniati. (2016). Pengaruh Profitabilitas terhadap Firm Value dengan Capital Structure sebagai Variabel Intervening. Jurnal Ilmu Dan Riset Manajemen, 5(4).

Sarasati, G. (2013). Analisis Pengaruh Profitabilitas, Price Earning Ratio, Struktur Aktiva, Operating Leverage, dan Pertumbuhan Penjualan terhadap Struktur Modal (Studi Kasus Pada Perusahaan Real Estate dan Property yang Terdaftar di BEI Periode 2008-2011). Universitas Diponogoro.

Suffah, \& Riduwan. (2016). Pengaruh Profitabilitas, Leverage, Ukuran Perusahaan dan Kebijakan Dividen pada Nilai Perusahaan. Jurnal IImu Dan Riset Akuntansi, 5(2).

Susanto, E. (2016). Pengaruh Profitabilitas, Kepemilikan Manajerial, dan Pertumbuhan Perusahaan (Growth) terhadap Struktur Modal dan Nilai Perusahaan, 8(3).

Utari, et al. (2014). Manajemen Keuangan. Jakarta: Mitra Wacana Media. 
Walsh, C. (2004). Key Management Ratio. Jakarta: Erlangga.

Wulandari, D. R. (2013). Pengaruh Profitabilitas, Operating Leverage, Likuiditas terhadap Nilai Perusahaan dengan Struktur Modal Sebagai Intervening. Accounting Analysis Journal, 2(4). 